\title{
Oryza Wild Species: An Alternative for Rice Breeding under Abiotic Stress Conditions
}

\author{
Vinícius Jardel Szareski1, Ivan Ricardo Carvalho1, Tiago Corazza da Rosa1, \\ Simone Morgan Dellagostin', Alan Junior de Pelegrin', Mauricio Horbach Barbosa1, \\ Osmarino Pires dos Santos ${ }^{1}$, Dionei Schmidt Muraro², Velci Queiróz de Souza ${ }^{3}$, Tiago Pedó1, \\ Tiago Zanatta Aumonde1, Camila Pegoraro ${ }^{1}$
}

\author{
${ }^{1}$ Federal University of Pelotas, Pelotas, Brazil \\ ${ }^{2}$ Federal University of Santa Maria, Santa Maria, Brazil \\ ${ }^{3}$ Federal University of Pampa, Bagé, Brazil \\ Email: viniciusszareski@gmail.com, carvalho.irc@gmail.com, tiagocorazza@live.com, simonedellagostin@hotmail.com, \\ pelegrinagro@gmail.com, osmarino.pires@fibria.com.br, dioneimuraro@hotmail.com, velciq@gmail.com, \\ tiago.pedo@gmail.com, tiago.aumonde@gmail.com, pegorarocamilanp@gmail.com
}

How to cite this paper: Szareski, V.J., Carvalho, I.R., da Rosa, T.C., Dellagostin, S.M., de Pelegrin, A.J., Barbosa, M.H., dos Santos, O.P., Muraro, D.S., de Souza, V.Q., Pedó, T., Aumonde, T.Z. and Pegoraro, C. (2018) Oryza Wild Species: An Alternative for Rice Breeding under Abiotic Stress Conditions. American Journal of Plant Sciences, 9, 1093-1104.

https://doi.org/10.4236/ajps.2018.96083

Received: January 12, 2018

Accepted: May 7, 2018

Published: May 10, 2018

Copyright (c) 2018 by authors and Scientific Research Publishing Inc. This work is licensed under the Creative Commons Attribution International License (CC BY 4.0).

http://creativecommons.org/licenses/by/4.0/

\begin{abstract}
Rice (Oryza sativa L.) presents a strategic role in social and economic levels. The aim of this study was to elucidate the presence of genetic variability for the genus Oryza, and the possibility of using genotypes with wild characteristics in rice breeding programs. The Oryza genus shows great genetic variability through wild genotypes available in the most varied environments around the world. The negative effects imposed by abiotic stresses such as flood, salinity, low temperatures, water deficiency and high temperatures may be minimized by the efficient identification of a genetic variability source from the Oryza genus. Among the main wild species presented by the Oryza genus, Oryza glumaepatula stands out being an active source of germplasm. The occurrence and preservation of genetic variability of Oryza genus is indispensable to obtain new rice genotypes, to guarantee food security for the human population, as well as to develop genotypes that adapt to climatic changes and natural adversities.
\end{abstract}

\section{Keywords}

Oryza sativa, Beeding, Germplasm, Source Genetic Variability

\section{Introduction}

Rice (Oryza sativa L.) presents a strategic role in social and economic levels. This crop is essential for human nutrition for supplying $20 \%$ of the calories consumed, being considered a staple food for more than half of the world's popula- 
tion [1] [2] [3] [4] [5]. Rice has an excellent nutritional balance, besides its wide adaptation in different environmental conditions. Therefore, it is considered a species of great potential to mitigate food scarcity in the world [6] [7].

According to the Food and Agriculture Organization of the United Nations [8], rice is characterized as the second most cultivated cereal in the world, with production around 516 million tons of grain, being sown in an area of approximately 160 million hectares and average yield of 3200 kilos of grains per hectare. The Asian continent accounts for $90 \%$ of the world's production, through China, India, Indonesia, Bangladesh, Vietnam, Thailand, Myanmar and Philippines. Brazil is the world's ninth largest producer and contributes with $1.6 \%$ of the worldwide total production. The country is the largest producer outside the Asian continent, accounting for 13 million tons of grain [5] [9].

The continued populational growth and increased food demands are among the factors of extreme importance for today's agriculture. Currently, about one billion people are chronically undernourished with an aggravated scenario in some specific situations. Unfortunately, there are no artifices capable of ensuring the agricultural system and providing appropriate conditions to feed a growing population expected to exceed nine billion people by the year 2050 [10].

An efficient use of natural resources and increased production are fundamental to meet the world's food needs [11] [12] [13]. However, the search for new agricultural frontiers and the availability of natural resources is limited, exposing crops to a series of disturbing events caused by floods, salinity, water deficit, high and low temperatures, negatively interfering on grain yield [2] [12] [14] [15] [16] [17] [18].

Complex behaviors of rice plants are evidenced in response to these not fully understood events, since some aspects are determined by a large set of genes that express the morphological, physiological and biochemical attributes. They dependent on the occurrence of stressors that trigger negative actions and accumulation of free radicals in the cells, decreasing seed and grain yield [19] [20] [21].

Genetic breeding is fundamental to overcome the impacts of climate changes and the scarcity of non-renewable energy reserves, characterizing itself as a sustainable activity and promoting food security. However, the procedures that enabled rice breeding also restricted its genetic variability, narrowing the genetic base of genotypes currently used in breeding programs. Thereby, it is necessary to search and rescue the variability through genotypes with a certain degree of rusticity, as these wild individuals will be sources of genes and alleles vital for developing new genotypes tolerant to abiotic stresses [22].

In this context, the aim of this study was to elucidate the presence of genetic variability for the genus Oryza, and the possibility of using genotypes with wild characteristics in rice breeding programs.

\section{Impact of Abiotic Stresses on Crop Development}

Waterlogging is characterized by a generalized environmental stress, where the 
rapid decline in oxygen diffusion rate $\left(\mathrm{O}_{2}\right)$ during flooding is accompanied by a decrease in the availability of oxygen to the cell. It reduces energy production and compromises photosynthetic rates of the plant and accumulation of reserves [23]. Although rice is considered a tolerant crop, only a few specific cultivars exhibit tolerance to prolonged submersion, since most genotypes die after 14 days of complete submersion [24] [25] [26].

Salinity is characterized as one of the most devastating abiotic stresses. Salinized soils represent about $20 \%$ of the world area cultivated with rice [7]. It may result in adverse effects on crop germination, vigor and yield [27]. When plants are exposed to saline stress, ionic balance results in the manifestation of several physiological processes, including sodium uptake and exclusion, which unbalance the dynamics of water and nutrients supply [28] [29]. Most rice plants are able to acclimatize under low or moderate salinities, however, their development is severely limited when salinity reaches high levels. Thus, plant survival and growth depend on phenotypic plasticity for cellular ionic balance [30] [31].

The effect of low-temperature stress is a major environmental factor limiting growth, development, yield and geographical distribution of the crop, especially in temperate and high-altitude areas [32] [33]. Low temperatures affect the growth and development of plants at any phenological stage, from germination to grain filling. During germination, the most common symptoms are low rates and delayed seedling emergence, which may compromise crop grain yield by $25 \%$ [32] [34]. During the vegetative stages, it is possible to occur yellowing of leaves, reduction of tillering and delay of plant growth. During the reproductive period, this stress may cause sterility of flowers, preventing the development of pollen grains and consequently the formation, filling and number of grains per panicle [32] [35] [36] [37] [38].

Water deficit stress is defined as limiting, since it affects the yield potential of many crops and is considered one of the most damaging stresses for rice cultivation [39] [40]. Its effects may vary among genotypes, phenological stages of development, severity and duration, compromising yield and its components [41] [42].

High-temperature stress is characterized as one of the major concerns, being considered a result of climate change [19] [43]. Most cultivated rice genotypes occur in regions where temperatures are above the optimum for plant growth and development $\left(22^{\circ} \mathrm{C}\right.$ to $\left.28^{\circ} \mathrm{C}\right)$, since any increase in average temperatures during sensitive periods of pant development may affect rice productive performance [44] [45]. The climatic variability is due to frequent episodes of high temperatures, which often coincide with the critical stages of crop development, such as flowering. There are predictions that rice yield might be reduced by up to $10 \%$ with an increase of $1{ }^{\circ} \mathrm{C}$ in the average temperature [46]. During seedlings initial growth, the occurrence of high temperatures impairs the establishment and uniformity of the field. In the anthesis, it may cause sterility and reduce the number of viable pollen grains, compromising rice yield. 


\section{The Oryza Genus}

The Oryza genus belongs to the Poaceae family, Glumiflorae order, Ehrhartoideae subfamily, and Oryzae tribe [47]. It is composed by 20 to 24 species (depending on the taxonomic references) and spread worldwide [3] [48] [49]. The variability of this genus evidences 11 distinct genomes (Box 1), which are AA, BB, CC, BBCC, CCDD, EE, FF, GG, KKLL, HHJJ and HHKK [50].

Box 1. Species of the Oryza genus, genome, number of chromosomes and geographic dispersion.

\begin{tabular}{|c|c|c|c|}
\hline Scientific name & $\begin{array}{c}\text { Genome } \\
\text { designation }\end{array}$ & $\begin{array}{l}\text { Number of } \\
\text { Chromosomes }\end{array}$ & Dispersion \\
\hline Oryza sativa L. & AA & Diploid, 2n = 24 & Tropical, Subtropical and Temperate Regions \\
\hline Oryza alta Swallen & CCDD & Tetraploid, $2 \mathrm{n}=48$ & Central and South America \\
\hline Oryza australiensis Domin & $\mathrm{EE}$ & Diploid, $2 \mathrm{n}=12$ & Tropical Australia \\
\hline Oryza barthii A. Chev. & AA & Diploid, $2 \mathrm{n}=24$ & Central, Oriental and Ocidental Africa \\
\hline Oryza brachyantha A. Chev. et Rhoer. & $\mathrm{FF}$ & Diploid, $2 \mathrm{n}=24$ & Central, Ocidental, and Oriental Africa \\
\hline Oryza coarctata Roxb. & HHKK & Tetraploid, $2 \mathrm{n}=24$ & Southern Asia and Myanmar \\
\hline Oryza eichingeri A. Peter & $\mathrm{CC}$ & Diploid, $2 \mathrm{n}=24$ & Oriental Africa and Meridional Asia \\
\hline Oryza glaberrima Steud. & $\mathrm{AA}$ & Diploid, $2 \mathrm{n}=24$ & Ocidental Africa \\
\hline Oryza glumaepatula Steud. & AA & Diploid, $2 \mathrm{n}=24$ & Latin America \\
\hline Oryza grandiglumis (Doell) Prod. & CCDD & Tetraploid, $2 \mathrm{n}=48$ & Latin America \\
\hline Oryza granulate Nees et Arn. ex Wat & GG & Diploid, $2 \mathrm{n}=24$ & Continental Asia \\
\hline Oryza indandamanica & GG & Diploid, $2 \mathrm{n}=24$ & Meridional Asia \\
\hline Oryza latifolia Desv. & CCDD & Tetraploid, $2 \mathrm{n}=48$ & South and Central America \\
\hline Oryza longiglumis Jansen & HHJJ & Tetraploid, $2 \mathrm{n}=48$ & Southern New Guinea \\
\hline Oryza longistaminata Chev. et Roehr. & AA & Diploid, 2n = 24 & Tropical Africa \\
\hline Oryza malampuzhaensis Krish. et Chand. & $\mathrm{BBCC}$ & Tetraploid, $2 \mathrm{n}=48$ & Meridional Asia \\
\hline Oryza meridionalis $\mathrm{Ng}$ & AA & Diploid, $2 \mathrm{n}=24$ & Australia and New Guinea \\
\hline Oryza meyeriana (Zoll. et Mor. ex Steud.) Baill. & GG & Diploid, $2 \mathrm{n}=24$ & Southeast Asia, Malaysian Peninsula \\
\hline Oryza minuta J.S. Presl. Ex. C.B. Presl. & $\mathrm{BBCC}$ & Tetraploid, $2 \mathrm{n}=48$ & Philippines and New Guinea \\
\hline Oryza neocaledonica Morat & GG (presumed) & Diploid, 2n = 24 (presumed) & New Caledonia \\
\hline Oryza nivara Sharma et Shastry & $\mathrm{AA}$ & Diploid, 12 & Asia \\
\hline Oryza officinalis Wall ex Watt & CC & Diploid, 12 & Asia and New Guinea \\
\hline OryzapunctataKotschyexSteud. & $\mathrm{BB}, \mathrm{BBCC}$ & $\begin{array}{l}\text { Diploide and tetraploide, } \\
\qquad 2 \mathrm{n}=24,2 \mathrm{n}=48\end{array}$ & Africa \\
\hline Oryza rhizomatis Vaughan & $\mathrm{CC}$ & Diploid, $2 \mathrm{n}=12$ & Meridional Asia \\
\hline Oryza ridleyi Hook. f. & $\mathrm{HHJJ}$ & Tetraploid, $2 \mathrm{n}=48$ & Asia \\
\hline Oryza rufipogon Griff. & AA & Diploid, $2 \mathrm{n}=24$ & Continental Asia \\
\hline Oryza schlechteri Pilger & $\begin{array}{l}\text { HHKK (requires } \\
\text { reconfirmation) }\end{array}$ & Tetraploid, $2 n=48$ & New Guinea \\
\hline
\end{tabular}

Source: [43], [52], [53], [54]. 
Species of the AA genome stand out due to the both cultivated species Oryza sativa L. (Asiatic rice) and Oryza glaberrima Steud (African rice) belong to this group [50]. Oryza sativa and Oryza glaberrima were independently domesticated from Oryza rufipogon in Asia, and Oryza barthii in Africa, respectively. Three ecogeographic groups were originated from Oryza sativa, indica, japonica and javanica or tropical japonica [51].

The Oryza glaberrima species is cultivated in West Africa, while Oryza sativa is widely distributed worldwide, being cultivated on all agricultural continents [55]. The Oryza sativa species is botanically characterized by presenting secondary ramifications in the panicles, persistent spikelets in the pedicel, and ligules up to $10 \mathrm{~mm}$ length. The Oryza glaberrima species do not present secondary ramification in the panicles, and are characterized by glumes, glabrous to little harsh leaves, red pericarp and ligules shorter than Oryza sativa [56].

Oryza indica and Oryza japonica subspecies differ in their morphological, physiological and genetic characteristics [57]. Among the most outstanding features of the two subspecies, there is grain shape, with Japonica genotypes presenting short, broad and thick grains, while Indica present long, narrow and slightly flat grains. Regarding the agronomic features, the subspecies Indica presents absence of awns, easy threshing, plants of light green color, large number of tilers and sensitivity to low temperatures. On the other hand, genotypes of the japonica subspecies present awns, tolerance to threshing, plants with dark green color, smaller number of tillers and tolerance to low temperatures, being the subspecies that represents $80 \%$ of the world's production [36].

Genotypes from Indic germplasm have spread throughout flooded regions of tropical lowlands of South and Southeast Asia, and China. In Brazil, most cultivated genotypes of irrigated rice are included in this group, being the results of local selections and crosses between genotypes (dwarf gene). In contrast, the japonica subspecies is cultivated both in uplands and elevations of tropical forests of Southeast Asia, as in subtropical regions with lower air temperature, including Northeast Asia, Europe, Western United States, Chile and Australia. The traditional rain fed rice genotypes grown in Brazil present genetic base from this group [58] [59] [60]. These two subspecies are clearly differentiated based on their genomic structure [61] [62]. Regarding the number of genetic resources, there are more than 500 thousand accessions conserved in germplasm banks worldwide, of which $70 \%$ of the world's collections are located in Asia [63].

Currently, breeding programs targeting the main agronomic attributes of rice, grain quality and yield are based on the search for germplasms source of genes and alleles that determine these characteristics. Therefore, wild accesses that present the necessary characteristics for acclimatization to abiotic stresses or disturbing conditions imposed by the growing environment are sought for breeding programs. In this context, it is necessary to identify where these accesses are located, which could be either the center of origin or genetic diversity of the species, as well as active germplasm banks that provide the necessary variability to breeders. 
In Latin America, the genetic basis of rice is considered narrow, and genetic vulnerability occurs when an organism lacks genes or alleles to tolerate determined environmental or biological stress, which leads to crop vulnerability [64]. As strategies to potentiate gains or genetic progress of the crop, it is possible to employ wild genotypes or those with low breeding process, and then direct the genes or allelic forms of interest to the progenies.

In Brazil, four wild rice species are found, which are also distributed throughout Central America and other South American countries. These are Oryza glumaepatula Steud, Oryza alta, Oryza grandiglumis and Oryza latifolia. Among these, Oryza glumaepatula stands out for plant breeding, which presents AA genome similar to grown species. It also is widely distributed and is rarely found in places outside the water. It grows on the banks of rivers and lakes, and its presence is related to the direct light incidence. Usually, this species is known as floating rice. In response to the elevation of water levels of rivers, a fast elongation of their internodes occurs, with plants reaching seven meters height. When these plants break down, they originate large floating populations [22].

After identifying where to search and which genotypes will be useful in breeding program, the breeder may employ conventional breeding techniques, such as hybridization and selection strategies, as well as biotechnological tools that allow introgression of specific genes or gene blocks that, when combined with agronomic ideotype genitors, will potentiate traits of interest in the progeny [65]. The literature presents some researches that elucidate breeding procedures aimed at developing and identifying genotypes more responsive to situations of abiotic stresses (Figure 1).

In this sense, wild species of the Oryza genus may be considered an alternative to increase rice genetic variability. Individuals of these species may be used as sources of genes and alleles in crossing blocks. Thereby, genes of interest are introgressed to fix important characteristics, potentiating the genetic variability of

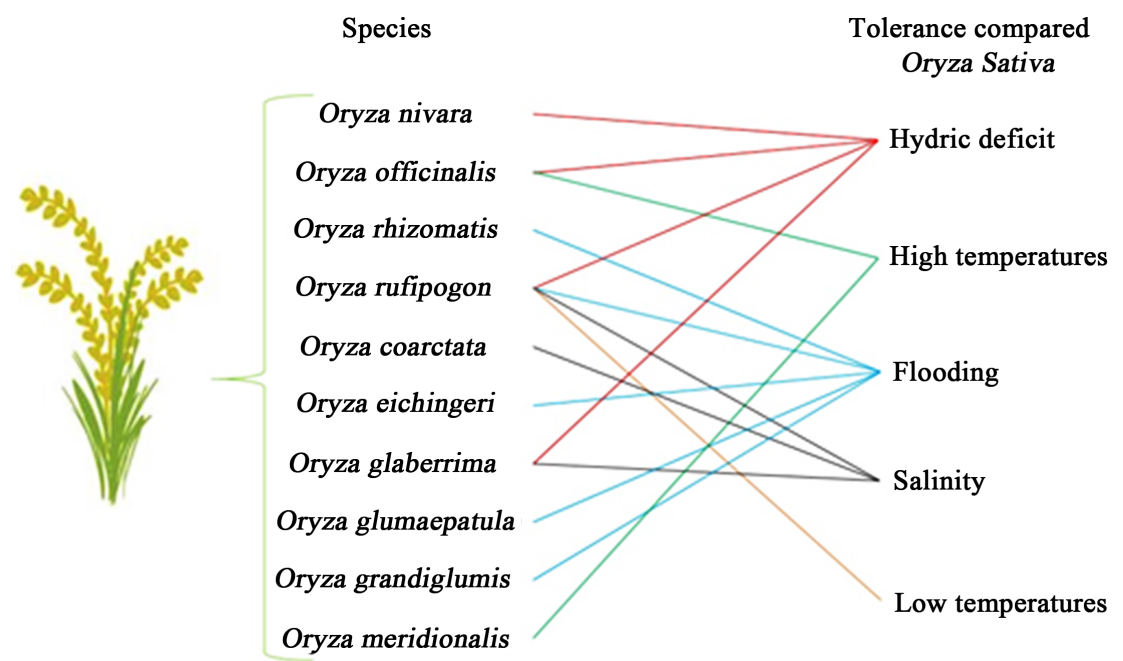

Figure 1. Tolerance to abiotic stresses found in accessions of species belonging to the Oryza genus [28] [31] [39] [66]-[73]. 
segregating population. It will increase the probability of identifying transgressive families in relation to their respective parents [31]. The search and identification of these superior families will allow the selection of genotypes along the segregating generations that show an escape from adverse conditions imposed by abiotic stresses inherent of the growing environments.

\section{Conclusions}

1) The Oryza genus shows great genetic variability through wild genotypes available in the most varied environments around the world.

2) The negative effects imposed by abiotic stresses such as flood, salinity, low temperatures, water deficiency and high temperatures may be minimized by the efficient identification of a genetic variability source from the Oryza genus.

3) Among the main wild species presented by the Oryza genus, Oryza glumaepatula stands out being an active source of germplasm.

4) The occurrence and preservation of genetic variability of Oryza genus is indispensable to obtain new rice genotypes, to guarantee food security for the human population, as well as to develop genotypes that adapt to climatic changes and natural adversities.

\section{References}

[1] IRGSP (International Rice Genome Sequencing Project) (2005) The Map-Based Sequence of the Rice Genome. Nature, 436, 793-800. https://doi.org/10.1038/nature03895

[2] Zhang, Q. and Wing, R.A. (2013) Genetics and Genomics of Rice: 2013. Springer, New York Heidelberg Dordrecht London, 402 p. https://doi.org/10.1007/978-1-4614-7903-1

[3] Jacquemin, J., Bhatia, D., Singh, K. and Wing, R.A. (2013) The International Oryza Map Alignment Project: Development of a Genus-Wide Comparative Genomics Platform to Help Solve the 9 Billion-People Question. Current Opinion in Plant Biology, 16, 1-10. https://doi.org/10.1016/j.pbi.2013.02.014

[4] Muthayya, S., Sugimoto, J.D., Montgomery, S. and Maberly, G.F. (2014) An Overview of Global Rice Production, Supply, Trade, and Consumption. Annals of the New York Academy of Sciences, 1324, 7-14. https://doi.org/10.1111/nyas.12540

[5] South Brazilian Society of Irrigated Rice (SOSBAI) (2016) Irrigated Rice: Research Publications for the South of Brazil. SOSBAI, Bento Gonçalves, 200.

[6] Gomes, A.S. and Magalhães Jr., A.M. (2004) Irrigated Rice in Southern Brazil. Embrapa Clima Temperado, Pelotas, 899 p.

[7] Zhou, Y., Yang, P., Cui, F., Zhang, F., Luo, X. and Xie, J. (2016) Transcriptome analysis of salt stress responsiveness in the seedlings of Dongxiang wild rice (Oryza rufipogon Griff.). PLoS ONE, 11, 146-242. https://doi.org/10.1371/journal.pone.0146242

[8] OECD/FAO (2017) OECD-FAO Agricultural Outlook 2017-2026, OECD Publishing, Paris. https://www.gene.affrc.go.jp/databases-plant_images_en.php

[9] Conab (2017) Follow-Up of Brazilian Grain Harvest: Eleventh Survey-Agosto/2017. http://www.conab.gov.br/ 
[10] Ash, C., Jasny, B.R., Malakoff, B.A. and Sugden, A.M. (2010) Feeding the Future. Science, 327, 797. https://doi.org/10.1126/science.327.5967.797

[11] Godfray, H.C., Beddington, J.R., Crute, I.R., Haddad, L., Lawrenc, E.D., Muir, J.F., Pretty, J., Robinson, S., Thomas, S.M. and Toulmin, C. (2010) Food Security: The Challenge of Feeding 9 Billion People. Science, 327, 812. https://doi.org/10.1126/science.1185383

[12] Foley, J.A., Ramnkutty, N., Brauman, K.A., Cassidy, E.S., Gerber, J.S., Johnston, M., Mueller, N.D., O’Connel, L.C., Ray, D.K., West, P.C., et al. (2011) Solutions for a Cultivated Planet. Nature, 478, 337-342. https://doi.org/10.1038/nature10452

[13] Palmgren, M.G., Edenbrandt, A.K., Vedel, S.E., Andersen, M.M., Landes, X., Østerberg, J.T., Falhof, J., Olsen, L.I., Christensen, S.B. and Sandøe, P. (2014) Are We Ready for Back-to-Nature Crop Breeding? Trends in Plant Science, 20, 155-164. https://doi.org/10.1016/j.tplants.2014.11.003

[14] Mueller, N.D., Gerber, J.S., Johnston, M., Ray, D.K., Ramankutty, N. and Foley, J.A. (2012) Closing Yield Gaps through Nutrient and Water Management. Nature, 490, 254-257. https://doi.org/10.1038/nature11420

[15] S, T. and GE, S. (2013) Understanding Rice Domestication and Implications for Cultivar Improvement. Current Opinion in Plant Biology, 16, 139-146. https://doi.org/10.1016/j.pbi.2013.03.003

[16] Bita, Ce. and Gerats, T. (2013) Plant Tolerance to High Temperature in a Changing Environment: Scientific Fundamentals and Production of Heat Stress-Tolerant Crops. Frontiers in Plant Science, 4, 273.

[17] Hirabayashi, H., Sasaki, K., Kambe, T., Gannaban, R.B., Miras, M.A., Mendioro, M.S., Simon, E.V., Lumanglas, P.D., Fujita, D., Takemoto-kuno, Y., et al. (2015) $q E M F 3$, a Novel QTL for the Early-Morning Flowering Trait from Wild Rice, Oryza officinalis, to Mitigate Heat Stress Damage at Flowering in Rice, O. sativa. Journal of Experimental Botany, 66, 1227-1236. https://doi.org/10.1093/jxb/eru474

[18] Edenbrandt, A.K., Vedel, S.E., Andersen, M.M., Landes, X., Østerberg, J.T., Falhof, J., Olsen, L.I., Christensen, S.B. and Sandøe, P. (2014) Are We Ready for Back-to-Nature Crop Breeding? Trends in Plant Science, 20, 155-164.

[19] Scafaro, A.P., Von Caemmerer, S. and Evans, J.R. (2011) Temperature Response of Mesophyll Conductance in Cultivated and Wild Oryza Species with Contrasting Mesophyll Cell Wall Thickness. Plant, Cell \& Environment, 34, 1999-2008. https://doi.org/10.1111/j.1365-3040.2011.02398.x

[20] Lei, D., Tan, L., Liu, F., Chen, L. and Sun, C. (2013) Identification of Heat-Sensitive QTL Derived from Common Wild Rice (Oryza rufipogon Griff.). Plant Science, 201-202, 121-127. https://doi.org/10.1016/j.plantsci.2012.12.001

[21] Hong, Y., Zhang, H., Huang, L., Li, D. and Song, F. (2016) Over Expression of a Stress-Responsive NAC Transcription Factor Gene ONAC022 Improves Drought and Salt Tolerance in Rice. Frontiers in Plant Science, 7, 4. https://doi.org/10.3389/fpls.2016.00004

[22] Magalhães Júnior, A.M. (2007) Genetic Resources of Rice (Oryza sativa L.) in Southern Brazil. Doctoral Thesis, Universidade Federal de Pelotas, 160 p.

[23] Bailey-Serres, J. and Voesenek, L. (2008) Flooding Stress: Acclimations and Genetic Diversity. Annual Review of Plant Biology, 59, 313-339. https://doi.org/10.1146/annurev.arplant.59.032607.092752

[24] Xu, K., Xu, X., Fukao, T., Canlas, P., Maghirang-Rodriguez, R., Heuer, S., Ismail, A.M., Bailey-Serres, J., Ronald, P.C. and Mackill, D.J. (2006) Sub1A Is an Ethy- 
lene-Response-Factor-Like Gene That Confers Submergence Tolerance to Rice. Nature, 442, 705-708. https://doi.org/10.1038/nature04920

[25] Jagadish, S.V.K., Muthurajan, R., Oane, R., Wheeler, T.R., Heuer, S., Bennett, J. and Craufurd, P.Q. (2010) Physiological and Proteomic Approaches to Address Heat Tolerance during Anthesis in Rice (Oryza sativa L.). Journal of Experimental Botany, 61, 143-156. https://doi.org/10.1093/jxb/erp289

[26] Okishio, T., Sasayama, D., Hirano, T., Akimoto, M., Itoh, K. and Azuma, T. (2015) Ethylene Is Not Involved in Adaptive Responses to Flooding in the Amazonian Wild Rice Species Oryza grandiglumis. Journal of Plant Physiology, 174, 49-54. https://doi.org/10.1016/j.jplph.2014.09.012

[27] Munns, R. and Tester, M. (2008) Mechanisms of Salinity Tolerance. Annual Review of Plant Biology, 59, 651-681. https://doi.org/10.1146/annurev.arplant.59.032607.092911

[28] Sengupta, S. and Majumder, A.L. (2010) Porteresia coarctata (Roxb.) Tateoka, a Wild Rice: A Potential Model for Studying Salt-Stress Biology in Rice. Plant, Cell \& Environment, 33, 526-542. https://doi.org/10.1111/j.1365-3040.2009.02054.x

[29] Chen, Y., Li, F., Ma, Y., Chong, K. and Xu, Y. (2013) Over Expression of OrbHLH001, a Putative Helix-Loop-Helix Transcription Factor, Causes Increased Expression of $A K T 1$ and Maintains Ionic Balance under Salt Stress in Rice. Journal of Plant Physiology, 170, 93-100. https://doi.org/10.1016/j.jplph.2012.08.019

[30] Hasegawa, P.M., Bressan, R.A., Zhu, J.K. and Bohnert, H.J. (2000) Plant Cellular and Molecular Responses to High Salinity. Annual Review of Plant Physiology and Plant Molecular Biology, 51, 463-499. https://doi.org/10.1146/annurev.arplant.51.1.463

[31] Platten, J.D., Egdane, J.A. and Ismail, A.M. (2013) Salinity Tolerance, Na+ Exclusion and Allele Mining of $H K T 1 ; 5$ in Oryza sativa and O. glaberrima: Many Sources, Many Genes, One Mechanism? BMC Plant Biology, 13, 32. https://doi.org/10.1186/1471-2229-13-32

[32] Cruz, R.P., Sperotto, R.A., Cargnelutti, D., Adamski, J.M., Terra, T.F. and Fett, J.P. (2013) Avoiding Damage and Achieving Cold Tolerance in Rice Plants. Food and Energy Security, 2, 96-119. https://doi.org/10.1002/fes3.25

[33] Wing, R.A. (2013) Genetics and Genomics of Rice. Springer, New York, Heidelberg, Dordrecht, London, $402 \mathrm{p}$.

[34] Dametto, A., Sperotto, R.A., Adamski, J.M., Blasi, E.A.R., Cargnelutti, D., De oliveira, L.F.V., Ricachenevsky, F.K., Fregonezi, J.N., Mariath, J.E.A., CRUZ, R.P., et al. (2015) Cold Tolerance in Rice Germinating Seeds Revealed by Deep RNA Seq Analysis of Contrasting Indica Genotypes. Plant Science, 238, 1-12.

https://doi.org/10.1016/j.plantsci.2015.05.009

[35] Ye, H., Du, H., Tang, N., Li., X. and Xiong, L. (2009) Identification and Expression Profiling Analysis of TIFY Family Genes Involved in Stress and Phytohormone Responses in Rice. Plant Molecular Biology, 71, 291-305.

https://doi.org/10.1007/s11103-009-9524-8

[36] Jena, K.K., Kim, S.M., Suh, J.P., Yang, C.I. and Kim, Y.J. (2012) Identification of Cold-Tolerant Breeding Lines by Quantitative Trait Loci Associated with Cold Tolerance in Rice. Crop Science, 51, 517-523.

https://doi.org/10.2135/cropsci2010.12.0733

[37] Zhang, Q., Chen, Q., Wang, S., Hong, Y. and Wang, Z. (2014) Rice and Cold Stress: Methods for Its Evaluation and Summary of Cold Tolerance-Related Quantitative Trait Loci. Rice, 7, 24. https://doi.org/10.1186/s12284-014-0024-3 
[38] Xiao, N., Huang, W.N., Li, A.H., Gao, Y., Li, H.Y., Pan, C.H., Ji, H., Zhang, X.X., Dai, X., Dai, Z.Y., et al. (2014) Fine Mapping of the $q L O P 2$ and $q P S R 2-1$ loci Associated with Chilling Stress Tolerance of Wild Rice Seedlings. Theoretical and Applied Genetics, 128, 173-185. https://doi.org/10.1007/s00122-014-2420-x

[39] Ndjiondjop, M.N., Cisse, F., Girma, G., Sow, M., Bocco, R., Djedatin, G. and Blandine, F. (2010) Morpho-Agronomic and Molecular Characterisation of Oryza glaberrima Germplasm from Mali. African Journal of Biotechnology, 9, 7409-7417. https://doi.org/10.5897/AJB2010.000-3312

[40] Jayaswal, P.K., Singh, B., Singh, P.K., Kumar, V., Mishra, S., Singh, N., Panda, K. and Singh, N.K. (2015) Natural Allelic Diversity in OsDREB $1 F$ Gene in the Indian Wild Rice Germplasm Led to Ascertain Its Association with Drought Tolerance. Plant Cell Reports, 34, 993-1004. https://doi.org/10.1007/s00299-015-1760-6

[41] Wang, D., Pan, Y., Zhao, X., Zhu, L., Fu, B. and Li, Z. (2011) Genome-Wide Temporal-Spatial Gene Expression Profiling of Drought Responsiveness in Rice. BMC Genomics, 12, 149. https://doi.org/10.1186/1471-2164-12-149

[42] Feng, F., Xu, X., Du, X., Tong, H., Luo, L. and Mei, H. (2012) Assessment of Drought Resistance among Wild Rice Accessions using a Protocol Based on Single-Tiller Propagation and PVC-Tube Cultivation. Australian Journal of Crop Science, 6, 1204-1211.

[43] Menguer, P.K., Sperotto, R.A. and Ricachenevsky, F.K. (2017) A Walk on the Wild Side: Oryza Species as Source for Rice Abiotic Stress Tolerance. Genetics and Molecular Biology, 40, 238-252. https://doi.org/10.1590/1678-4685-gmb-2016-0093

[44] Krishnan, P., Ramakrishnan, B., Reddy, K.R. and Reddy, V.R. (2011) High-Temperature Effects on Rice Growth, Yield, and Grain Quality. Advances in Agronomy, 111, 87-206. https://doi.org/10.1016/B978-0-12-387689-8.00004-7

[45] Korres, N.E., Norsworthy, J.K., Burgos, N.R. and Oosterhuis, D.M. (2017) Temperature and Drought Impacts on Rice Production. An Agronomic Perspective Regarding Short- and Long-Term Adaptation Measures. Water Resources and Rural Development, 9, 12-27. https://doi.org/10.1016/j.wrr.2016.10.001

[46] Peng, S., Huang, J., Sheehy, J.E., Laza, R.C., Visperas, R.M., Zhong, X., Centeno, G.S., Khush, G.S. and Cassman, K.G. (2004) Rice Yields Decline with Higher Night Temperature from Global Warming. Proceedings of the National Academy of Sciences of the United States, 101, 9971-9975.

https://doi.org/10.1073/pnas.0403720101

[47] Vaughan, D.A., Morishima, H. and Kadowaki, K. (2003) Diversity in the Oryzagenus. Current Opinion in Plant Biology, 6, 139-146. https://doi.org/10.1016/S1369-5266(03)00009-8

[48] Stein, J.C., Yu, Y., Copetti, D, et al. (2018) Genomes of 13 Domesticated and Wild Rice Relatives Highlight Genetic Conservation, Turnover and Innovation across the Genus Oryza. Nature Genetics, 50, 285-296. https://doi.org/10.1038/s41588-018-0040-0

[49] Atwell, B.J., Wang, H. and Scafaro, A.P. (2014) Could Abiotic Stress Tolerance in Wild Relatives of Rice Be Used to Improve Oryza sativa? Plant Science, 215-216, 48-58. https://doi.org/10.1016/j.plantsci.2013.10.007

[50] Londo, J.P., Chiang, Y.C., Hung, K.H., Chiang, T.Y. and Schaal, B.A. (2006) Phylogeography of Asian Wild Rice, Oryza rufipogon, Reveals Multiple Independent Domestications of Cultivated Rice, Oryza sativa. Proceedings of the National Academy of Sciences, 103, 9578-9583. https://doi.org/10.1073/pnas.0603152103

[51] Win, K.T., Yamagata, Y., Doi, K., Uyama, K., Nagai, Y., Toda, Y., Kani, T., Ashikari, 
M., Yasui, H. and Yoshimura, A. (2016) A Single Base Change Explains the Independent Origin of and Selection for the Nonshattering Gene in African Rice Domestication. New Phytologist, 213, 1925-1935. https://doi.org/10.1111/nph.14290

[52] Kellogg, E.A. (2009) The Evolutionary History of Ehrhartoideae, Oryzeae, and Oryza. Rice, 2, 1-14. https://doi.org/10.1007/s12284-009-9022-2

[53] Bhatia, D., Singh, K. and Wing, R.A. (2013) The International Oryza Map Alignment Project: Development of a Genus-Wide Comparative Genomics Platform to Help Solve the 9 Billion-People Question. Current Opinion in Plant Biology, 16, $1-10$.

[54] Hu, H. and Xiong, L. (2014) Genetic Engineering and Breeding of Drought Resistant Crops. Annual Review of Plant Biology, 65, 715-741. https://doi.org/10.1146/annurev-arplant-050213-040000

[55] Shivrain, V.K., Burgos, N.R., Agrama, H.A., Lawton-Rauh, A., Lu, B., Sales, M.A., Boyett, V., Gealy, D.R. and Moldenhauer, K.A.K. (2010) Genetic Diversity of Weedy Red Rice (Oryza sativa) in Arkansas. Weed Research, 50, 289-302.

[56] Pereira, J.A. (2002) Cultura do arroz no Brasil: Subsídios para a sua história. Teresina, Embrapa Meio-Norte, 226 p.

[57] Chang, T.T. (2003) Origin, Domestication, and Diversification. In: Smith, C.W. and Dilday, R.H., Eds., Rice: Origin, History, Technology, and Production, John Wiley \& Sons, Inc., Hoboken, 3-25.

[58] Pinheiro, B.S. (1998) Morphology and Growth of the Rice Plant. Goiânia, EMBRAPA-CNPAF, Palestra Apresentada No I International Course on Genetic Improvement of Rice, Goiânia.

[59] Khush, G.S., Brar, D.S., Virk, P.S., Tang, S.X., Malik, S.S., Busto, G.A., Lee, Y.T., Mcnally, R., Trinh, L.N., Jiang, Y. and Shata, M.A.M. (2003) Classifying Rice Germaplasm by Isozyme Polymorphism and Origin of Culticated Rice. IRRI Discussion Paper Series, Los Baños, Philippines, No. 46, 279 p.

[60] Garris, A.J., Tai, T.H., Coburn, J., Kresovich, S. and Mccouch, S. (2005) Genetic Structure and Diversity in Oryza sativa L. Genetics, 169, 1631-1638. https://doi.org/10.1534/genetics.104.035642

[61] Iza, W.A.T. (2008) The Process of Rice Domestication: A New Model Based on Recent Data. Rice, 1, 127-134. https://doi.org/10.1007/s12284-008-9014-7

[62] Vaughan, D.A., Lu, B.R. and Tomooka, N. (2008) Was Asian Rice (Oryza sativa) Domesticated More than Once? Rice, 1, 16-24.

[63] Genesys. Global Gateway to Genetic Resources. https://www.genesys-pgr.org/pt/c/rice

[64] Raimondi, J.V., Marschalek, R. and Nodari, O. (2014) Genetic Base of Paddy Rice Cultivars of Southern Brazil. Crop Breeding and Applied Biotechonology, 14, 194-199. https://doi.org/10.1590/1984-70332014v14n3a29

[65] Szareski, V.J., Carvalho, I.R., Kehl, K., Levien, A.M., Nardino, M., Demari, G., Lautenchleger, F., Souza, V.Q., Pedo, T. and Aumonde, T.Z. (2017) Univariate, Multivariate Techniques and Mixed Models Applied to the Adaptability and Stability of Wheat in the Rio Grande do Sul State. Genetics and Molecular Research, 16, 1-13. https://doi.org/10.4238/gmr16039735

[66] Singh, B.P., Jayaswal, P.K., Singh, B., Singh, P.K., Kumar, V., Mishra, S., Singh, N., Panda, K. and Singh, N.K. (2015) Natural Allelic Diversity in OsDREB1F Gene in the Indian Wild Rice Germplasm Led to Ascertain Its Association with Drought Tolerance. Plant Cell Reports, 34, 993-1004. 
https://doi.org/10.1007/s00299-015-1760-6

[67] Ishimaru, T., Hirabayashi, H., Ida, M., Takai, T., San-oh, Ya., Yoshinaga, S., Ando, I., Ogawa, T. and Kondom (2010) A Genetic Resource for Early-Morning Flowering Trait of Wild Rice Oryza officinalis to Mitigate High Temperature-Induced Spikelet Sterility at Anthesis. Annals of Botany, 106, 515-520.

https://doi.org/10.1093/aob/mcq124

[68] Xu, X., Du, X., Tong, H., Luo, L. and Mei, H. (2012) Assessment of Drought Resistance among Wild Rice Accessions using a Protocol Based on Single-Tiller Propagation and PVC-Tube Cultivation. Australian Journal of Crop Science, 6, 1204-1211.

[69] Niroula, R.K., Pucciariello, C., Ho, V.T., Novi, G., Fukao, T. and Perata, P. (2012) $S U B 1 A$-Dependent and -Independent Mechanisms Are Involved in the Flooding Tolerance of Wild Rice Species. The Plant Journal, 72, 282-293. https://doi.org/10.1111/j.1365-313X.2012.05078.x

[70] Hattori, Y., Nagai, K., Furukawa, S., Song, X.J., Kawano, R., Sakakibara, H., Wu, J., Matsumoto, T., Yoshimura, A., Kitano, H., et al. (2009) The Ethylene Response Factors SNORKEL1 and SNORKEL2 Allow Rice to Adapt to Deep Water. Nature, 460, 1026-1030. https://doi.org/10.1038/nature08258

[71] Tian, L., Tan, L., Liu, F., Cai, H. and Sun, C. (2011) Identification of Quantitative Trait Loci Associated with Salt Tolerance at Seedling Stage from Oryza rufipogon. Journal of Genetics and Genomics, 38, 593-601. https://doi.org/10.1016/j.jgg.2011.11.005

[72] Huang, W.N., Li, A.H., Gao, Y., Li, H.Y., Pan, C.H., Ji, H., Zhang, X.X., Dai, X., Dai, Z.Y., et al. (2014) Fine Mapping of the $q L O P 2$ and $q P S R 2-1$ loci Associated with Chilling Stress Tolerance of Wild Rice Seedlings. Theoretical and Applied Genetics, 128, 173-185.

[73] Sasayama, D., Hirano, T., Akimoto, M. and Itohk, A.T. (2014) Growth Promotion and Inhibition of the Amazonian Wild Rice Species Oryza grandiglumis to Survive Flooding. Planta, 240, 459-469. https://doi.org/10.1007/s00425-014-2100-8 